\title{
PENINGKATAN MOTIVASI BELAJAR SISWA UNTUK PENCAPAIAN KOMPETENSI MENGGAMBAR PROPORSI TUBUH MELALUI METODE PEER TEACHING
}

\author{
Dianita Anggar Kusuma \\ Program Studi Pendidikan Teknologi dan Kejuruan PPs UNY \\ dian.nita.anggar.kusuma@gmail.com \\ Sri Wening \\ Faklutas Teknik Universitas Negeri Yogyakarta \\ riwening@yahoo.co.id
}

\begin{abstract}
Abstrak
Penelitian ini bertujuan untuk mengetahui (1) pelaksanaan pembelajaran menggambar proporsi tubuh wanita dengan menerapkan metode peer teaching, (2) peningkatan motivasi belajar siswa melalui penerapan metode peer teaching, (3) peningkatan pencapaian kompetensi menggambar proporsi tubuh wanita melalui penerapan metode peer teaching di SMK Diponegoro Depok, Yogyakarta. Penelitian ini merupakan penelitian tindakan kelas yang terdiri dari tiga siklus dengan desain penelitian model Kemmis dan Mc. Taggart. Subjek dalam penelitian ini adalah 34 siswa kelas XI Busana Butik pada tahun pelajaran 2013/2014. Teknik pengambilan subjek penelitian dilakukan dengan purposive sampling. Pengumpulan data menggunakan metode observasi, metode tes, dan metode dokumentasi. Instrumen yang digunakan yaitu lembar observasi, lembar penilaian unjuk kerja, dan tes. Validitas instrumen dalam penelitian ini menggunakan validitas isi dengan meminta pendapat para ahli. Uji reliabilitas menggunakan konsistensi antar rater. Teknik analisis data yang digunakan adalah analisis deskriptifkuantitatif. Hasil penelitian menunjukkan bahwa pembelajaran menggambar proporsi tubuh wanita telah terlaksana sangat baik (100\%), sesuai dengan fase dan unsur metode peer teaching. Motivasi belajar siswa siklus pertama dalam kategori sedang, yaitu mencapai 53,9\%, pada siklus kedua motivasi belajar siswa dalam kategori sedang, yaitu mencapai 60,6\%, dan siklus ketiga motivasi belajar siswa dalam kategori tinggi, yaitu mencapai 75,3\%. Pencapaian kompetensi menggambar proporsi tubuh wanita siklus pertama siswa yang memenuhi standar KKM sebanyak $44,12 \%$, siklus kedua siswa yang memenuhi standar KKM sebanyak 61,76\%, dan siklus ketiga siswa yang memenuhi standar KKM sebanyak 79,41\%.
\end{abstract}

Kata kunci: metode peer teaching, motivasi belajar, kompetensi menggambar proporsi tubuh wanita.

\section{IMPROVING STUDENTS' LEARNING MOTIVATION TO ATTAIN THE COMPETENCY IN DRAWING BODY PROPORTION THROUGH PEER TEACHING METHOD}

\begin{abstract}
This teaching research study aims to investigate: (1) the implementation of the teaching of drawing female body proportion by applying the peer teaching method, (2) the improvement of the students' motivation through the application of the peer teaching method, and (3) the improvement of the attainment of the competency in drawing female body proportion through the application of the peer teaching method in SMK Diponegoro Depok, Yogyakarta. This research was a classroom action research study consisting of three cycles employing the research model by Kemmis and McTaggart. The study was conducted in SMK Diponegoro Depok Yogyakarta. The research subjects were 34 grade XI students of Boutique Clothing in the academic year of 2013/2014. The technic of research subject taking is conducted by purposive sampling. The data collecting methods were observation, test, and documentation methods. The instrument is observation sheet, performance assessment sheet, and test. The instrument validity testing used the content validity, and was assessed through expert judgment and the reliability was assessed by means of the inter-rater consistency technique. The data were analyzed using the quantitative descriptive technique. The results of the study show that the teaching of drawing female body proportion was well implemented, in accordance with the phase and component of the peer teaching method. In cycle I their learning motivation was in the moderate category, namely $53.9 \%$, in cycle II it was in the moderate category, namely $60.6 \%$, and in cycle III it was in the high category, namely $75.3 \%$. The attainment of the competency in drawing female body proportion in cycle I $44.12 \%$ of the students attained the MMC, in cycle II $61.76 \%$ of the students attained the MMC, and in cycle III $79.41 \%$ of the students attained the MMC.
\end{abstract}

Keywords: peer teaching method, learning motivation, competency in fashion drawing female body proportion. 


\section{PENDAHULUAN}

SMK Diponegoro Depok Yogyakarta adalah salah satu SMK di Kabupaten Sleman yang membuka program keahlian Busana Butik yang berfungsi membekali peserta didik dengan ketrampilan dan pengetahuan dalam bidang busana. Salah satu mata pelajarannya adalah menggambar busana atau fashion drawing. Mata pelajaran ini merupakan mata pelajaran produktif yang diajarkan pada kelas $\mathrm{X}$ dan kelas XI, menekankan pada ranah aspek afektif, kognitif dan psikomotorik.

SMK memiliki karakteristik yang berbeda dengan satuan pendidikan lainnya. SMK dirancang untuk menyiapkan siswa atau lulusan yang siap memasuki dunia kerja dan mampu mengembangkan sikap profesional di bidangnya. Namun SMK dituntut bukan hanya sebagai penyedia tenaga kerja yang siap bekerja pada lapangan kerja yang sesuai dengan kebutuhan dunia usaha/dunia industri, tetapi juga dituntut untuk mengembangkan diri pada jalur wirausaha, agar dapat maju dalam berwirausaha walaupun dalam kondisi dan situasi apapun. Pendidikan kejuruan perlu mengajarkan dan melatih siswa dalam menguasai kompetensi dan kemampuan lain yang dibutuhkan untuk menjalani kehidupan yang berguna sebagai modal untuk pengembangan dirinya dikemudian hari.

Tujuan SMK sebagai bentuk satuan pendidikan kejuruan sebagaimana ditegaskan dalam pasal 15 UU SISDIKNAS, merupakan pendidikan menengah yang mempersiapkan siswa terutama untuk bekerja dalam bidang tertentu.

Berdasarkan hasil survei dan wawancara dengan guru dan siswa jurusan Busana Butik SMK Diponegoro Depok Yogyakarta, bahwa kompetensi menggambar proporsi tubuh merupakan kompetensi yang dianggap sulit oleh siswa. Pencapaian kompetensi menggambar busana sekitar 29,41\% siswa sudah memenuhi standar KKM, sedangkan $70,59 \%$ sisanya masih belum memenuhi standar KKM. Hal tersebut dikarenakan pelaksanaan pembelajaran menggambar busana di SMK Diponegoro Depok Yogyakarta kurang variatif yaitu masih bersifat teacher center, dimana guru menyampaikan materi dan mendemonstrasikan cara menggambar, secara bersamaan pula siswa mengerjakan tugas. Sehingga hal ini mengakibatkan motivasi belajar siswa menjadi kurang. Berdasarkan hasil observasi pada saat pelaksanaan pembelajaran menggambar busana menunjukkan motivasi belajar siswa masih rendah, hal ini dapat dilihat dari beberapa motivasi belajar siswa yaitu seperti kurang tanya jawab dan siswa cenderung pasif. Selain itu kurangnya pembimbingan secara individu dari guru kepada siswa. Hal ini tak lepas dari keterbatasan jumlah guru yaitu satu guru untuk membimbing 34 siswa dalam kelas. Siswa melakukan hal-hal yang tidak berhubungan dengan pelajaran dan kurang serius dalam mengikuti pembelajaran dan mengerjakan tugas. Siswa merasa bosan dengan pembelajaran yang ada.

Menurut Suryabrata (2006:232) belajar adalah membawa perubahan sehingga didapatkan kecakapan baru yang terjadi karena usaha (dengan sengaja). Hal tersebut senada dengan Sardiman (2009:2), salah satu pertanda bahwa seseorang telah belajar adalah adanya perubahan tingkah laku dalam dirinya baik menyangkut perubahan yang bersifat pengetahuan (kognitif), keterampilan (psikomotorik), maupun nilai dan sikap (afektif). Ditambahkan oleh Syah (1995:91), bahwa perubahan tingkah laku yang timbul akibat proses kematangan, keadaan gila, mabuk, lelah dan jenuh tidak dapat dipandang sebagai proses belajar.

Dari beberapa pendapat tentang belajar di atas, maka dapat dikatakan bahwa belajar merupakan usaha yang dilakukan secara sadar untuk memperoleh perubahan perilaku berupa pengetahuan, keterampilan, dan sikap setelah mendapatkan pengalaman-pengalaman tertentu. Proses belajar terjadi karena siswa memperoleh sesuatu yang ada di lingkungan sekitar. Lingkungan yang dipelajari oleh siswa berupa keadaan alam, benda-benda, hewan, tumbuh-tumbuhan, manusia, atau hal-hal yang dijadikan bahan belajar. Tindakan belajar tentang suatu hal tersebut tampak sebagai perilaku yang tampak dari luar (Dimyati, Mudjiono, 2009:7).

Motivasi dan belajar merupakan dua hal yang saling mempengaruhi. Motivasi adalah keadaan internal yang membangkitkan, mengarahkan dan mempertahankan perilaku (Wol- 
fook, 2009:192). Dalam proses belajar, motivasi sangat penting karena seseorang yang tidak memiliki motivasi dalam belajar maka ia tidak akan melakukan aktivitas belajar.

Dengan demikian tujuan dari pembelajaran yaitu pencapaian kompetensi tidak terpenuhi. Hal ini sependapat dengan Mc. Ashan dalam Mulyasa (2002) yang mengemukakan bahwa kompetensi diartikan sebagai pengetahuan, keterampilan dan kemampuan yang dikuasai oleh seseorang yang telah menjadi bagian dari dirinya, sehingga ia dapat melakukan perilaku-perilaku kognitif, afektif, dan psikomotorik dengan sebaik-baiknya.

Menurut Muhammad Joko Susilo (2007:97), kompetensi merupakan perpaduan dari pengalaman, keterampilan, nilai dan sikap yang direfleksikan dalam kebiasaan berpikir dan bertindak. Mc. Ashan (Mulyasa, 2002) mengemukakan bahwa kompetensi:

“... is a knowledge, skills, and abilities or capabilities that a person achieves, which become part of his or her being to the exent he or she can satisfactorily perform particular cognitive, affective, and psychomotor behaviors".

Dalam hal ini kompetensi diartikan sebagai pengetahuan, keterampilan dan kemampuan yang dikuasai oleh seseorang yang telah menjadi bagian dari dirinya, sehingga ia dapat melakukan perilaku-perilaku kognitif, afektif, dan psikomotorik dengan sebaik-baiknya. Sejalan dengan itu, Finch \& Crunkilton (2005) mengartikan kompetensi sebagai penguasaan terhadap suatu tugas, keterampilan, sikap, dan apresiasi yang diperlukan untuk menunjang keberhasilan. Dalam SKN Busana "Custommade" (2003), kompetensi diartikan sebagai kemampuan yang dibutuhkan untuk melakukan atau melaksanakan pekerjaan yang dilandasi oleh pengetahuan, keterampilan dan sikap kerja.

Dari beberapa pendapat di atas dapat disimpulkan bahwa kompetensi diartikan sebagai pengetahuan, keterampilan dan kemampuan yang dikuasai oleh seseorang yang telah menjadi bagian dari dirinya, sehingga ia dapat melakukan perilaku-perilaku kognitif, afektif, dan psikomotorik dengan sebaik-baiknya untuk menunjang keberhasilan.
Dalam Muhammad Joko Susilo (2007:99) Gardon menjelaskan beberapa aspek atau ranah yang terkandung dalam konsep kompetensi sebagai berikut:

1. Pengetahuan (knowledge) yaitu kesadaran dalam bidang kognitif.

2. Pemahaman (understanding) yaitu kedalaman kognitif, dan afektif yang dimiliki oleh individu.

3. Kemampuan (skill) adalah sesuatu yang dimiliki oleh individu untuk melakukan tugas atau pekerjaan yang dibebankan kepadanya.

4. Nilai (value) adalah suatu standar perilaku yang telah diyakini dan secara psikologis telah menyatu dalam diri seseorang.

5. Sikap (attitude) yaitu perasaan (senang tidak senang, suka - tidak suka) atau reaksi terhadap suatu rangsangan yang datang dari luar.

6. Minat (interest) adalah kecenderungan seseorang untuk melakukan sesuatu perbuatan.

Siswa yang telah memiliki kompetensi mengandung arti bahwa siswa telah memahami, memaknai dan memanfaatkan materi pelajaran yang telah dipelajarinya. Dengan perkataan lain, ia telah dapat melakukan sesuatu berdasarkan ilmu yang telah dimilikinya, yang pada tahap selanjutnya menjadi kecakapan hidup. Dengan demikian belajar tidak hanya cukup sampai mengetahui dan memahami saja tetapi juga memanfaatkan materi pelajaran yang telah dipelajari.

Kompetensi siswa yang harus dimilki selama proses dan sesudah pembelajaran adalah kemampuan kognitif (pemahaman, penalaran, aplikasi, analisis, observasi, identifikasi, investigasi, eksplorasi, koneksi, komunikasi, inkuiri, hipotesis, konjektur, generalisasi, kreativitas, pemecahan masalah), kemampuan afektif (pengendalian diri yang mencakup kesadaran diri, pengelolaan suasana hati, pengendalian impulsi, motivasi aktivitas positif, empati), dan kemampuan psikomotorik (sosialisasi dan kepribadian yang mencakup kemampuan argumentasi, presentasi, prilaku).

Melihat permasalahan yang ada maka dalam hal ini strategi pembelajaran yang digu- 
nakan harus ditingkatkan guna keberhasilan proses pembelajaran, tercapainya kompetensi siswa, dan untuk memperbaiki motivasi belajar siswa. Salah satu hal yang dapat menentukan keberhasilan pembelajaran adalah metode pembelajaran. Menurut Rusman (2012) untuk merealisasikan strategi pembelajaran maka diperlukan suatu metode yang dapat digunakan untuk mengimplementasikan rencana pembelajaran yang telah disusun, agar tujuan pembelajaran yang telah disusun tersebut dapat tercapai secara optimal.

Metode merupakan cara yang digunakan untuk mengimplementasikan rencana pembelajaran yang disusun dalam bentuk kegiatan nyata dan praktis untuk mencapai tujuan pembelajaran. Metode ini berkaitan dengan aktivitas mengajar guru. Mengajar merupakan kegiatan guru untuk menciptakan sistem lingkungan yang memungkinkan terjadinya proses belajar bagi siswa berdasarkan prinsip-prinsip tertentu pada model pengajaran tertentu.

Menurut Joyce, Weil dan Chalhoun (2009:7), metode pengajaran sebenarnya juga dapat dianggap sebagai metode pembelajaran, dikarenakan saat guru membantu siswa memperoleh informasi, gagasan, keterampilan, nilai, cara berpikir, dan tujuan mengekspresikan dirinya sendiri, guru sebenarnya sedang mengajari siswa belajar. Sehingga dari paparan tersebut, dapat dikatakan bahwa guru perlu bijak menentukan metode pembelajaran yang sesuai dengan permasalahan yang ingin diperbaiki dalam suatu pelajaran atau dinilai paling efektif untuk mencapai tujuan pembelajaran. Metode pembelajaran menentukan bagaimana peran guru dan peran siswa dalam pembelajaran, sehingga di dalam proses pembelajaran wajib diterapkan model pembelajaran.

Berdasarkan penjelasan di atas dapat disimpulkan bahwa metode pembelajaran sebagai suatu pelaksanaan kegiatan belajar mengajar yang memperhatikan prinsip-prinsip mengajar tertentu yang memiliki hubungan saling terkait dengan model pembelajaran untuk mendukung ketercapaian tujuan pembelajaran. Metode pembelajaran perlu terlebih dahulu direncanakan secara sistematis. Guru harus mampu memilih dan menentukan metode mengajar yang terbaik sesuai tujuan pembelajaran.
Salah satu metode yang dapat digunakan adalah metode peer teaching. Dalam bahasa Indonesia, peer teaching adalah tutor sebaya. Menurut Dina Mellita (2008:36), tutor sebaya adalah seorang atau beberapa orang siswa yang ditunjuk dan ditugaskan untuk membantu siswa yang mengalami kesulitan belajar. Metode peer teaching sebagai metode dalam model pembelajaran kooperatif, dimana model pembelajaran kooperatif merupakan model pembelajaran yang menitik beratkan pada aktifitas belajar siswa. Dalam hal ini, sebagian besar aktifitas berpusat pada siswa, yakni mempelajari materi pelajaran, berdiskusi untuk memecahkan masalah. Dengan interaksi yang efektif dimungkinkan semua kelompok dapat menguasai materi pada tingkat yang relatif sejajar (Agus Supriyono, 2010:54). Siswa dituntut aktif dalam proses belajar mengajar, dan guru hanya bersifat sebagai fasilitator. Sehingga metode ini selain digunakan untuk memperbaiki proses pembelajaran juga dapat digunakan dalam peningkatan motivasi belajar siswa untuk pencapaian kompetensi. Selain itu di dalam model pembelajaraan kooperatif terdapat unsur pemberian penghargaan kepada siswa, hal ini dapat meningkatkan motivasi belajar siswa untuk mencapai kompetensi tertinggi dan mendapatkan penghargaan.

Penelitian ini dibatasi mengenai penerapan metode peer teaching sebagai upaya peningkatan motivasi belajar untuk pencapaian kompetensi menggambar proporsi tubuh wanita di SMK Diponegoro Depok Yogyakarta.

Metode peer teaching sebagai metode dalam model pembelajaran kooperatif. Materi pada mata pelajaran menggambar busana adalah pada materi menggambar proporsi tubuh wanita. Hal ini dikarenakan menyesuaikan dengan keberlangsungan pembelajaran di sekolah. Menggambar proporsi tubuh wanita merupakan awal siswa kelas XI untuk menggambar desain busana.

Motivasi belajar siswa yang akan diamati yaitu selama proses pembelajaran menggambar proporsi tubuh wanita dengan menggunakan lembar observasi. Kompetensi siswa yang akan dinilai adalah kompetensi dasar pada ranah kognitif, psikomotorik, dan afektif. Penelitian ini dikhususkan pada siswa kelas XI 
Busana Butik SMK Diponegoro Depok Yogyakarta, karena ketercapaian KKM pada kelas ini masih rendah.

Motivasi dan belajar merupakan dua hal yang saling mempengaruhi. Motivasi adalah keadaan internal yang membangkitkan, mengarahkan dan mempertahankan perilaku (Wolfook, 2009:192). Dalam proses belajar, motivasi sangat penting karena seseorang yang tidak memiliki motivasi dalam belajar maka ia tidak akan melakukan aktivitas belajar.

Motivasi adalah salah satu faktor dalam diri siswa yang mempengaruhi keefektifan belajar di dalam kelas. Schunk, et al (2010:5) mengemukakan bahwa motivasi memiliki hubungan dengan kemampuan belajar. Artinya, motivasi mempengaruhi proses belajar dan proses pembelajaran mempengaruhi motivasi. Proses pembelajaran bergantung pada kemampuan guru dalam memberikan motivasi kepada siswa, dalam hal ini guru dapat memberikan motivasi belajar dengan variasi mengajar melalui metode pembelajaran.

Beberapa definisi dari para ahli mengenai motivasi secara garis besar mengandung makna yang hampir sama. Seperti yang dinyatakan oleh Wolfook (2009:372) bahwa "motivation is usually defined as an internal state that arouses, directs, and maintain behavior". Atau dengan kata lain motivasi dipengaruhi oleh keadaan internal yang ada dalam dirinya, keadaan internal inilah yang dapat membangkitkan, mengarahkan, dan mempertahankan perilaku seseorang. Santrock (2011:441) menambahkan dalam pembelajaran siswa membutuhkan pertalian atau pergaulan untuk membentuk, memelihara, dan memulihkan hubungan kedekatan dengan teman sebaya dan guru yang mendukung pembelajaran. Oleh karena itu motivasi belajar siswa membutuhkan pertalian yang kuat diantara komponen pembelajaran seperti teman sebaya dan guru di dalam lingkungan belajar.

Definisi selanjutnya menurut McLean (2009:7) menyatakan bahwa "motivation is all the reason behind why we behave as we do and revolves around intentionality". Dari definisi tersebut, maka motivasi merupakan alasan seseorang berperilaku dan segala hal disekitarnya secara sengaja.
Houtson (1995:9), menyatakan bahwa "the concept of motivation is somewhat dependent on one's starting point and in terms of schooling, on the current context". Dari pernyataan tersebut, konsep motivasi merupakan beberapa hal yang berkaitan dengan titik awal yang berhubungan dengan sekolah pada konteks tertentu.

Kemudian dari para ahli psikologi, Slavin (2008:105), mengintisaikan bahwa "motivasi merupakan proses internal yang mengaktifkan, menuntun dan mempertahankan perilaku dari waktu ke waktu". Apabila dilihat dari konteks pembelajaran maka motivasi merupakan sesuatu yang dapat menyebabkan siswa mau untuk belajar, membuat siswa untuk tetap belajar, dan menentukan apa yang ingin siswa pelajari.

Mc. Donald pada Hamalik (2011:106), memaparkan bahwa motivasi merupakan perubahan energi dalam diri seseorang yang ditandai dengan timbulnya perasaan dan reaksi untuk mencapai tujuan. Kemudian ditambah oleh Baharuddin dan Wahyuni (2007:22), yang menyatakan bahwa motivasilah yang mendorong siswa ingin melakukan kegiatan belajar.

Dalam kegiatan belajar, Sardiman (2010:73) mengemukakan bahwa motivasi adalah keseluruhan daya penggerak di dalam subjek untuk melakukan aktivitas-aktivitas tertentu demi mencapai suatu tujuan. Dalam hal ini motivasi dipandang sebagai daya penggerak dari dalam diri siswa yang menimbulkan kegiatan belajar. Lebih jelas Hamzah (2007:23) menyebutkan bahwa motivasi adalah dorongan internal dan eksternal pada siswa yang sedang belajar untuk mengadakan perubahan tingkah laku, pada umumnya dengan beberapa indikator atau unsur yang mendukung. Hal itu sangat berperan besar dalam keberhasilan seseorang dalam belajar.

Indikator motivasi seperti yang diuraikan Hamzah (2007:23) adalah sebagai berikut: (1) adanya hasrat dan keinginan berhasil; (2) adanya dorongan dan kebutuhan dalam belajar; (3) adanya harapan dan cita-cita masa depan; (4) adanya penghargaan dalam belajar; (5) adanya kegiatan yang menarik dalam belajar; (6) adanya lingkungan belajar yang kondusif, sehingga memungkinkan seorang siswa dapat belajar dengan baik. Hal ini mengindikasikan bahwa 
tanpa adanya motivasi maka tidak akan ada tujuan dan suatu tingkah laku yang terorganisasi. Motivasi belajar siswa tercermin karena siswa telah berhasil dalam menempuh dan menyelesaikan pelajarannya. Keberhasilan siswa dalam menyelesaikan permasalahan dan mendapatkan pujian dari guru akan membangkitkan semangat menjadi meningkat, siswa akan lebih terpacu motivasi belajarnya jika mendapat hasil baik, dan menurun jika hasilnya jelek.

Djamarah (2008:148) menambahkan bahwa dalam proses belajar, motivasi sangat diperlukan, sebab seseorang yang tidak mempunyai motivasi dalam belajar, tak akan mungkin melakukan aktivitas belajar. Sehingga dari berbagai pemaparan mengenai motivasi belajar, dapat diambil suatu kesimpulan bahwa motivasi belajar siswa mempengaruhi kegiatan belajar siswa yang berhubungan dengan pencapaian tujuan belajar siswa. Dalam hal ini motivasi belajar perlu ditingkatkan untuk mengetahui pengaruh penggunaan metode Peer Teaching pada kompetensi Menggambar Busana.

Penelitian ini bertujuan untuk mengetahui 1) pelaksanaan pembelajaran menggambar proporsi tubuh wanita dengan menerapkan metode Peer Teaching di SMK Diponegoro Depok Yogyakarta, 2) peningkatan motivasi belajar siswa melalui penerapan metode Peer Teaching di SMK Diponegoro Depok Yogyakarta, dan 3) peningkatan pencapaian kompetensi menggambar proporsi tubuh wanita melalui penerapan metode Peer Teaching di SMK Diponegoro Depok Yogyakarta.

Manfaat teoritis dari penelitian ini yaitu sebagai pengetahuan tentang bagaimana teori penerapan metode peer teaching untuk meningkatkan motivasi belajar siswa dalam pencapaian kompetensi menggambar proporsi tubuh wanita. Selain itu dapat dijadikan bahan kajian studi yang berkaitan dengan proses belajar mengajar, khususnya pembelajaran menggambar busana. Manfaat praktisnya yaitu: 1) bagi peneliti, dengan penelitian ini diharapkan peneliti dapat lebih memahami tentang pengaruh pemilihan metode pembelajaran terhadap motivasi belajar siswa dan kompetensi; 2) bagi sekolah, dengan penelitian ini diharapkan dapat digunakan sebagai bahan masukan dan pertimbangan untuk menggunakan metode peer teaching pada kompetensi menggambar proporsi tubuh wanita dan menjadikan salah satu pendekatan dalam pembelajaran yang dapat digunakan untuk meningkatkan motivasi belajar siswa untuk pencapaian kompetensi; 3) bagi Prodi Pendidikan Teknologi dan Kejuruan, dengan adanya penelitian ini dapat digunakan sebagai tolok ukur kemampuan mahasiswa serta dapat digunakan sebagai salah satu referensi untuk mengembangkan penelitian selanjutnya.

\section{Pertanyaan Penelitian}

Berkaitan dengan fokus penelitian dan mengacu pada kajian teori, maka pertanyaan penelitian dalam penelitian ini yaitu:

1. Bagaimana pelaksanaan pembelajaran menggambar proporsi tubuh wanita dengan menerapkan metode peer teaching dengan langkah-langkah: 1) menyampaikan tujuan dan memotivasi siswa; 2) menyajikan informasi; 3) mengorganisasikan siswa kedalam kelompok-kelompok belajar; 4) membimbing kelompok bekerja dan belajar; 5) evaluasi; dan 6) pemberian penghargaan di SMK Diponegoro Depok Yogyakarta?

2. Bagaimana peningkatan motivasi belajar siswa yang meliputi: 1) tekun; 2) ulet; 3) mandiri; 4) menyukai kegiatan variatif; dan 5) dapat berargumen melalui penerapan metode peer teaching di SMK Diponegoro Depok Yogyakarta?

3. Bagaimana peningkatan pencapaian kompetensi yang terdiri dari ranah kognitif, psikomotor, dan afektif dalam menggambar proporsi tubuh wanita melalui penerapan metode peer teaching di SMK Diponegoro Depok Yogyakarta?

\section{METODE PENELITIAN}

\section{Jenis Penelitian}

Penelitian ini merupakan penelitian tindakan kelas yang terdiri dari tiga siklus dengan desain penelitian model Kemmis dan Taggart. Alur penelitian tindakan kelas terdiri dari 1) Perencanaan, 2) Tindakan dan Pengamatan, 3) Refleksi. 


\section{Waktu Penelitian}

Waktu penelitian adalah waktu yang digunakan selama penelitian berlangsung. Dalam penelitian ini, waktu penelitian pada saat pemberian tindakan kelas dengan menggunakan pembelajaran kooperatif tipe dengan metode peer teaching disesuaikan dengan waktu yang telah diberikan oleh pihak sekolah dan jadwal pembelajaran menggambar busana pada semester ganjil tahun ajaran 2013/2014 yaitu bulan Juli 2013.

\section{Deskripsi Tempat Penelitian}

Tempat penelitian adalah tempat dimana proses studi yang digunakan untuk memperoleh pemecahan masalah penelitian berlangsung (Sukardi, 2008:53). Penelitian tindakan kelas ini dilaksanakan di SMK Diponegoro Depok Yogyakarta, pada mata pelajaran menggambar busana dan tepatnya pada siswa kelas XI Busana Butik tahun pelajaran 2013/2014 yang beralamat di Jalan Sembego Maguwoharjo, Depok, Yogyakarta.

\section{Subjek dan Karakteristiknya}

Teknik pengambilan subjek penelitian dilakukan dengan purposive sampling yaitu teknik pengambilan subjek penelitian dengan pertimbangan tertentu. Alasan mengambil subjek penelitian kelas XI Busana Butik karena siswa kelas tersebut menurut guru mata pelajaran yang bersangkutan, motivasi belajar dalam pembelajaran masih dikatakan rendah, pencapaian kompetensi juga masih banyak yang di bawah KKM.

Objek penelitian adalah sumber diperolehnya data dari penelitian yang dilakukannya. Dalam penelitian tindakan kelas ini objek penelitiannya adalah peningkatan motivasi belajar untuk pencapaian kompetensi menggambar proporsi tubuh wanita melalui metode peer teaching pada mata pelajaran menggambar busana di SMK Diponegoro Depok Yogyakarta.

\section{Rencana Tindakan}

Penelitian tindakan kelas ini menggunakan model Kemmis dan Taggart. Model Kemmis dan Taggart terdiri dari tiga komponen yaitu 1) Perencanaan, merupakan tindakan yang tersusun dan mengarah pada tindakan, fleksibel, dan refleksi; 2) Tindakan dan pengamatan, adalah tindakan yang dilakukan secara sadar dan terkendali yang merupakan variasi praktik yang cermat dan bijaksana. Dan pengamatan berfungsi untuk mendokumentasikan pengaruh tindakan terkait bersama prosesnya; 3) Refleksi, merupakan kegiatan mengingat dan merenungkan kembali suatu tindakan persis seperti yang telah dicatat dalam observasi.

\section{Data dan Teknik Pengumpulan Data}

Data pelaksanaan pembelajaran menggambar proporsi tubuh diperoleh dari hasil pengamatan kegiatan-kegiatan pembelajaran menggambar proporsi tubuh yang di dalamnya terdapat fase dan unsur metode peer teaching. Data motivasi belajar siswa diperoleh dari hasil pengamatan motivasi belajar siswa selama pelaksanaan pembelajaran menggambar busana meliputi tekun, ulet, mandiri, menyukai kegiatan variatif, dan dapat berargumen. Data pencapaian kompetensi menggambar proporsi tubuh, meliputi kompetensi ranah belajar kognitif, psikomotorik, dan afektif. Kompetensi kognitif diperoleh dari nilai tes pilihan ganda, kompetensi psikomotorik diperoleh dari nilai unjuk kerja menggambar proporsi tubuh, kompetensi afektif diperoleh dari pengamatan motivasi belajar siswa selama pembelajaran menggambar proporsi tubuh.

\section{Instrumen}

Instrumen dalam penelitian ini digunakan untuk melihat seberapa jauh pembelajaran dengan metode peer teaching memberi dampak terhadap peningkatan motivasi belajar untuk pencapaian kompetensi menggambar proporsi tubuh wanita. Instrumen dalam penelitian tindakan kelas ini terdiri dari empat instrumen yaitu lembar observasi, lembar penilaian unjuk kerja, tes, dan catatan lapangan. Lembar observasi digunakan untuk mengetahui proses pembelajaran menggambar proporsi tubuh wanita yang dilakukan oleh guru dengan metode peer teaching dan motivasi belajar siswa yang sekaligus digunakan untuk mengetahui kompetensi siswa ranah afektif. Lembar penilaian unjuk kerja digunakan untuk mengetahui kompetensi siswa ranah psikomotor. Tes digunakan untuk mengetahui kompetensi siswa ranah kognitif. 


\section{Uji Validitas dan Reliabilitas Instrumen}

Validitas yang digunakan pada penelitian ini adalah validitas isi. Untuk menguji validitas isi dapat digunakan pendapat dari ahli (experts judgment). Butir instrumen disusun dan dikonsultasikan kepada dosen pembimbing dan guru, kemudian meminta pertimbangan pada para ahli untuk diperiksa dan dievaluasi secara sistematis apakah butir-butir instrumen tersebut telah mewakili apa yang hendak diukur.

Pengujian realibilitas pada penelitian ini menggunakan reliabilitas konsistensi antar rater. Reliabilitas konsistensi antar rater yaitu prosedur pemberian skor terhadap suatu instrumen yang dilakukan oleh beberapa orang rater (Saifuddin Azwar, 2009). Menurut Ahcmad Rohani (2004) keterandalan antar rater yaitu koefisiensi kesepakatan antar pengamat (rater). Wahyu Widhiarso (2009:13) mengemukakan reliabilitas antar rater dipakai menilai konsistensi beberapa rater dalam menilai suatu obyek, semakin banyak kemiripan hasil penilaian antara satu rater dengan rater lainnya maka koefisien yang dihasilkan tinggi.

Uji reliabilitas instrument observasi, lembar penilaian unjuk kerja, dan angket dilakukan dengan menggunakan rater yaitu instrumen dinilai keajegkannya dengan meminta prndapat dari beberapa ahli (expert judgment).

\section{Teknik Analisis Data}

Teknik analisis data yang digunakan dalam penelitian ini adalah deskriptif kuantitatif. Analisis data secara deskriptif digunakan untuk mendeskripsikan data penelitian apa adanya, dan untuk mendapatkan gambaran mengenai fakta yang ada. Sedangkan untuk kuantitatif digunakan untuk mengukur pencapaian kompetensi siswa dengan sistem ratarata kelas pada hasil evaluasi di setiap siklus.

\section{Indikator Keberhasilan}

1. Dilihat dari keterlaksanaan pembelajaran, indikator keberhasilan penelitian ini mengacu pada unsur dan fase metode peer teaching. Apabila seluruh fase dan unsur metode peer teaching telah diterapkan maka pembelajaran menggambar proporsi tubuh wanita sudah terlaksana baik sesuai dengan metode peer teaching.
2. Dari segi motivasi belajar, mengacu pada E Mulyasa (2002:131) bahwa dari segi proses pembelajaran atau pembentukan kompetensi dikatakan berhasil dan berkualitas apabila seluruh kelas (setidak-tidaknya $75 \%)$ peserta didik terlibat secara aktif baik fisik, mental, maupun sosial dalam proses pembelajaran. Maka pada penelitian ini motivasi belajar siswa dikatakan meningkat apabila $75 \%$ siswa terlibat secara aktif dalam pembelajaran menggambar proporsi tubuh wanita. Siswa memiliki motivasi belajar yang tinggi apabila tingkah lakunya menunjukkan beberapa indikator motivasi belajar sebagai berikut: tekun, ulet, mandiri, menyukai kegiatan variatif, dan dapat berargumen.

3. Dari segi kompetensi siswa, mengacu pada Departemen Pendidikan Nasional dalam kriteria dan Indikator Keberhasilan Pembelajaran (2008) yang menyatakan bahwa sebuah pembelajaran dikatakan tuntas apabila lebih dari $75 \%$ siswa telah memenuhi standar kriteria ketuntasan minimal yang ditentukan oleh pihak sekolah. Dalam hal ini sekolah yang bersangkutan adalah SMK Diponegoro Depok Yogyakarta, yang menentukan KKM untuk mata pelajaran menggambar busana adalah 70, maka keberhasilan dalam penelitian ini adalah apabila $\geq$ 75\% siswa mencapai nilai KKM yaitu 70 .

Apabila peningkatan yang terjadi disetiap siklus belum memenuhi indikator maka penelitian ini berlanjut pada siklus berikutnya. Namun apabila peningkatan yang terjadi sudah memenuhi indikator keberhasilan maka penelitian ini dapat diakhiri.

\section{HASIL PENELITIAN DAN PEMBAHASAN}

\section{Hasil Penelitian}

\section{Pra Siklus}

Pelaksanaan pembelajaran pra siklus adalah pembelajaran yang berpusat pada guru, sehingga siswa cenderung pasif. Aktivitas belajar siswa masih rendah, terlihat dari keaktifan bertanya siswa yang kurang, siswa belum 
memiliki keasadaran menulis hal-hal yang relevan dengan pembelajaran, adanya siswa yang melakukan hal-hal yang tidak mendukung proses pembelajaran seperti bermain $\mathrm{hp}$, mengobrol, bercanda. Siswa kurang serius mengerjakan tugas menggambar proporsi tubuh, sehingga pada waktu pengumpulan tugas, siswa melebihi batas waktu yang ditentukan. Dari segi penggunaan model dan metode pembelajaran, belum terlihat guru menggunakan model dan metode pembelajaran yang variatif yang dapat meningkatkan motivasi belajar siswa. Media yang digunakan juga belum sepenuhnya memberikan pemahaman pada siswa dalam belajar. Berdasarkan hasil wawancara dengan beberapa siswa, pelaksanaan pembelajaran yang kurang variatif seperti ini cenderung membuat siswa merasa jenuh. Pada pra siklus ini siswa yang mencapai Kriteria Ketuntasan Minimal sebesar 29,41\% atau sejumlah 10 siswa, sedangkan $70,29 \%$ sisanya atau 24 siswa belum mencapai Kriteria Ketuntasan Minimal. Sesuai penjelasan hasil observasi dan wawancara tidak berstruktur ini dapat diambil kesimpulan bahwa:

1. Pelaksanaan pembelajaran sebelum tindakan adalah pembelajaran yang berpusat pada guru. Guru memberikan meteri dan mendemonstrasikan menggambar bagianbagian tubuh. Siswa masih cenderung pasif dalam mengikuti pembelajaran.

2. Rendahnya motivasi belajar siswa, tercermin dari sebagian besar siswa yang masih melakukan aktivitas-aktivitas yang tidak mendukung pembelajaran, dan kurangnya partisipasi aktif siswa terhadap keberhasilan pembelajaran, karena pembelajaran masih berpusat pada guru. Mengacu pada pedapat E. Mulyasa yang menyatakan bahwa pembentukan kompetensi dikatakan berhasil dan berkualitas apabila seluruh kelas atau sebagian besar (setidak- tidaknya $75 \%$ ) peserta didik terlibat secara aktif baik fisik, mental, maupun sosial dalam proses pembelajaran. Meskipun banyak siswa yang belum paham tetapi aktivitas bertanya sangat rendah, siswa enggan untuk menanyakan kesulitan yang dihadapi, dan lebih memilih diam karena ketidakpahamannya.
3. Pencapaian kompetensi siswa yang masih rendah yaitu siswa yang mencapai KKM sebesar $29,41 \%$ atau sejumlah 10 siswa, sedangkan $70,29 \%$ sisanya atau 24 siswa belum mencapai KKM.

Berdasarkan permasalahan tersebut di atas maka tujuan yang akan direalisasikan dari penelitian ini adalah memperbaiki motivasi belajar siswa dengan menerapkan metode peer teaching sehingga motivasi belajar siswa dan kompetensi pada mata pelajaran menggambar nusana dapat meningkat.

\section{Siklus 1}

Siklus pertama penerapan metode peer teaching di SMK Diponegoro Depok Yogyakarta terdiri dari 3 komponen yaitu perencanaan, tindakan dan pegamatan, refleksi. Perencanaan siklus pertama ini dibuat oleh peneliti berkolaborasi dengan guru mata pelajaran menggambar busana. Tindakan siklus pertama adalah melaksanakan pembelajaran menggambar proporsi tubuh wanita di kelas XI Busana Butik. Pelaksanaan pembelajaran menerapkan enam fase pembelajaran kooperatif yaitu guru menyampaikan tujuan dan memotivasi siswa, menyajikan informasi, mengorganisasikan siswa ke dalam kelompok-kelompok belajar, membimbing kelompok bekerja dan belajar, evaluasi, dan pemberian penghargaan. Dan unsur metode peer teaching yaitu menempatkan siswa sebagai peers dalam kelompok untuk membimbing teman kelompok dalam belajar.

Pengamatan dilakukan terhadap pelaksanaan pembelajaran, motivasi belajar siswa dan pencapaian kompetensi menggambar proporsi tubuh wanita.

Hasil penerapan metode peer teaching pada pembelajaran menggambar proporsi tubuh wanita menunjukkan bahwa pelaksanaan pembelajaran sudah berjalan cukup lancar. Pelaksanaan pembelajaran terdiri dari 3 tahap tindakan yaitu kegiatan awal, kegiatan inti, dan kegiatan akhir.

Iklim belajar yang berlangsung sudah mulai kondusif. Kegiatan guru dalam menyampaikan materi dengan metode pembelajaran peer teaching mendapatkan respon yang cukup baik dari siswa. Pola interaksi guru dengan siswa dan siswa dengan siswa belum maksi- 
mal. Saat pembagian kelompok, banyak siswa yang protes karena teman sekelompok tidak sesuai dengan yang mereka harapkan. Hal ini mengakibatkan interaksi antar siswa dalam kelompok masih terlihat kurang, walaupun pada hari sebelumnya para peers sudah diberi arahan. Siswa masih bekerja sendiri tanpa peduli dengan teman satu kelompoknya. Saat berdiskusi kelompok siswa masih belum bisa tenang dalam mengerjakan tugas, masih terdengar kegaduhan di sana sini, efek dari siswa yang mengobrol terlalu keras. Sebagian besar siswa belum dapat diarahkan untuk saling membantu teman satu kelompoknya.

Pendekatan belajar yang dilakukan bertujuan untuk meningkatkan motivasi belajar untuk pencapaian kompetensi siswa. Teknik mengajar sudah baik dan tepat untuk meningkatkan motivasi belajar untuk pencapaian kompetensi menggambar proporsi tubuh wanita. Bedasarkan hasil pengamatan dengan menggunakan lembar observasi pelaksanaan pembelajaran, pada siklus pertama terdapat dua unsur yang belum terlaksana dengan baik. Sehingga dapat diambil kesimpulan bahwa $90 \%$ pembelajaran menggambar proporsi tubuh wanita sudah terlaksana sangat baik sesuai dengan fase dan unsur metode peer teaching.

Dari segi motivasi belajar siswa, masih banyak siswa belum memiliki kesadaran mencatat hal-hal yang relevan dengan pembelajaran. Masih ada siswa yang kurang serius mengikuti pembelajaran, dengan melakukan hal-hal yang tidak mendukung keberhasilan proses belajar. Sehingga berdasarkan hasil pengamatan siklus pertama motivasi belajar siswa dalam kategori sedang, dengan nilai total butir amatan adalah 91 dan mencapai prosentase sebesar 53,5\%.

Pencapaian kompetensi menggambar proporsi tubuh pada siklus pertama meliputi 3 ranah belajar yaitu kognitif, psikomotorik, dan afektif. Pada siklus pertama jumlah siswa yang tuntas sebanyak 15 siswa atau $44,12 \%$ dan yang belum tuntas sebanyak 19 siswa atau $55,88 \%$. Kategori pencapaian kompetensi siswa berdasarkan Kriteria Ketuntasan Minimal pada siklus 1 adalah sebagai berikut:
Tabel 1. Pencapaian Kompetensi Siswa Siklus 1 Berdasarkan KKM

\begin{tabular}{lcc}
\hline Kategori & Frekuensi & Presentase \\
\hline Tuntas & 15 & $44,12 \%$ \\
Belum tuntas & 19 & $55,88 \%$ \\
Jumlah & 34 & $100 \%$ \\
\hline
\end{tabular}

\section{Siklus 2}

Siklus kedua penerapan metode peer teaching di SMK Diponegoro Depok Yogyakarta, pelaksanaannya terdapat 3 komponen yaitu perencanaan, tindakan dan pengamatan, refleksi. Perencanaan pada siklus kedua berdasarkan pada refleksi siklus pertama. Dimana akan dilakukan perbaikan terhadap pelaksanaan unsur metode peer teaching guru akan memberikan arahan pada siswa bagaimana seharusnya kerja kelompok peer teaching, siswa diharapkan dapat saling membantu teman satu kelompoknya, saling bertukar pemahaman untuk mengerjakan tugas kelompok.

Hasil penerapan metode peer teaching pada pembelajaran menggambar proporsi tubuh wanita menunjukkan bahwa pelaksanaan pembelajaran sudah berjalan lancar. Pelaksanaan pembelajaran terdiri dari 3 tahap tindakan yaitu pendahuluan, pelaksanaan pembelajaran, dan penutup.

Iklim belajar yang berlangsung sudah mulai kondusif. Kegiatan guru dalam menyampaikan materi dengan metode pembelajaran peer teaching mendapatkan respon yang baik dari siswa. Pola interaksi guru dengan siswa dan siswa dengan siswa sudah mulai maksimal. Saat pembagian kelompok, tidak ada siswa yang protes lagi. Siswa mulai berinteraksi dengan teman satu kelompoknya. Saat berdiskusi kelompok siswa cukup tenang dalam mengerjakan tugas. Sebagian besar siswa sudah dapat diarahkan untuk saling membantu teman satu kelompoknya.

Pendekatan belajar yang dilakukan bertujuan untuk meningkatkan motivasi belajar untuk pencapaian kompetensi siswa. Teknik mengajar sudah baik dan tepat untuk meningkatkan motivasi belajar untuk pencapaian kompetensi menggambar proporsi tubuh wanita. Bedasarkan hasil pengamatan dengan menggunakan lembar observasi pelaksanaan pembelajaran, 
pada siklus kedua pelaksanaan pembelajaran terlaksana dengan baik. Sehingga dapat diambil kesimpulan bahwa 100\% pembelajaran menggambar proporsi tubuh wanita sudah terlaksana sangat baik sesuai dengan fase dan unsur metode peer teaching.

Motivasi belajar siswa terjadi peningkatan. Siswa memperhatikan guru, dan media yang digunakan dengan seksama. Siswa mulai aktif bertanya. Keseriusan siswa mengerjakan tugas juga bertambah terbukti sudah tidak banyak siswa yang melakukan hal-hal yang mengganggu proses belajar, sehingga sudah mulai banyak siswa pada siklus kedua dapat mengumpulkan tugas tepat pada waktunya. Pada siklus kedua motivasi belajar siswa dalam kategori sedang, dengan nilai total butir amatan 103 dan mencapai prosentase sebesar $60,6 \%$.

Pencapaian kompetensi menggambar proporsi tubuh wanita pada siklus kedua ini meliputi 3 ranah belajar yaitu kognitif, psikomotorik, dan afektif. Pada siklus kedua jumlah siswa yang tuntas sebanyak 21 siswa atau $61,76 \%$ dan jumlah siswa yang belum tuntas sebanyak 13 siswa atau sebanyak 38,24\%. Kategori pencapaian kompetensi siswa berdasarkan KKM pada siklus 2 adalah sebagai berikut:

Tabel 2. Pencapaian Kompetensi Siswa Siklus 2 Berdasarkan KKM

\begin{tabular}{lll}
\hline Kategori & Frekuensi & Presentase \\
\hline Tuntas & 21 & $61,76 \%$ \\
Belum tuntas & 13 & $38,24 \%$ \\
Jumlah & 34 & $100 \%$ \\
\hline
\end{tabular}

\section{Siklus 3}

Siklus ketiga penerapan metode peer teaching di SMK Diponegoro Depok Yogyakarta, pelaksanaannya terdapat 3 komponen yaitu perencanaan, tindakan dan pengamatan, refleksi. Perencanaan pada siklus ketiga berdasarkan pada refleksi siklus kedua. Dimana akan dilakukan perbaikan terhadap pelaksanaan unsur metode peer teaching, guru akan memberikan arahan pada siswa bagaimana seharusnya kerja kelompok peer teaching, sehingga siswa mengerti bagaimana mereka seharusnya berdiskusi kelompok.
Hasil penerapan metode peer teaching pada pembelajaran menggambar proporsi tubuh wanita menunjukkan bahwa pelaksanaan pembelajaran sangat berjalan lancar. Pelaksanaan pembelajaran terdiri dari 3 tahap tindakan yaitu pendahuluan, pelaksanaan pembelajaran, dan penutup.

Iklim belajar yang berlangsung sangat kondusif. Kegiatan guru dalam menyampaikan materi dengan metode pembelajaran peer teaching mendapatkan respon yang baik dari siswa. Pola interaksi guru dengan siswa dan siswa dengan siswa sudah maksimal. Saat pembagian kelompok, tidak ada siswa yang protes lagi. Siswa berinteraksi dengan teman satu kelompoknya dengan baik. Saat berdiskusi kelompok siswa cenderung tenang dalam mengerjakan tugas. Sebagian besar siswa sudah dapat diarahkan untuk saling membantu teman satu kelompoknya.

Pendekatan belajar yang dilakukan bertujuan untuk meningkatkan motivasi belajar untuk pencapaian kompetensi siswa. Teknik mengajar sudah baik dan tepat untuk meningkatkan motivasi belajar untuk pencapaian kompetensi menggambar proporsi tubuh wanita. Bedasarkan hasil pengamatan dengan menggunakan lembar observasi pelaksanaan pembelajaran, pada siklus ketiga pelaksanaan pembelajaran terlaksana dengan sangat baik. Sehingga dapat diambil kesimpulan bahwa $100 \%$ pembelajaran menggambar proporsi tubuh wanita sudah terlaksana sangat baik sesuai dengan fase dan unsur metode peer teaching.

Motivasi belajar siswa terjadi peningkatan. Siswa memperhatikan guru, dan media yang digunakan dengan seksama. Siswa banyak yang aktif bertanya. Keseriusan siswa mengerjakan tugas juga bertambah terbukti sudah tidak adanya siswa yang melakukan hal-hal yang mengganggu proses belajar, sehingga banyak siswa pada siklus ketiga dapat mengumpulkan tugas tepat pada waktunya. Pada siklus ketiga motivasi belajar siswa dalam kategori tinggi, dengan nilai total butir amatan 128 dan mencapai prosentase sebesar $75,3 \%$.

Pencapaian kompetensi menggambar proporsi tubuh wanita pada siklus ketiga ini meliputi 3 ranah belajar yaitu kognitif, psiko- 
motorik, dan afektif. Pada siklus ketiga jumlah siswa yang tuntas sebanyak 27 siswa atau $79,41 \%$ dan jumlah siswa yang belum tuntas sebanyak 7 siswa atau sebanyak $20,59 \%$. Kategori pencapaian kompetensi siswa berdasarkan KKM pada siklus 3 adalah sebagai berikut:

Tabel 3. Pencapaian Kompetensi Siswa Siklus 3 Berdasarkan KKM

\begin{tabular}{lcc}
\hline Kategori & Frekuensi & Presentase \\
\hline Tuntas & 27 & $79,41 \%$ \\
Belum tuntas & 7 & $20,59 \%$ \\
Jumlah & 34 & $100 \%$ \\
\hline
\end{tabular}

\section{Pembahasan}

\section{Penerapan Metode Peer Teaching Pada Pembelajaran Menggambar Proporsi Tubuh Wanita}

Pembelajaran menggambar proporsi tubuh wanita dengan menerapkan metode peer teaching ini terdapat 3 tahap yaitu pendahuluan, pelaksanaan dan penutup. Berdasarkan data yang diperoleh pada pelaksanaan pembelajaran dengan menerapkan metode peer teaching pada siklus pertama yaitu $90 \%$ pembelajaran berlangsung sangat baik sesuai dengan fase dan unsur metode peer teaching. Pada siklus kedua pelaksanaan pembelajaran menggambar proporsi tubuh wanita terlaksana 100\% sangat baik sesuai dengan fase dan unsur metode peer teaching. Pada siklus ketiga pelaksanaan pembelajaran menggambar proporsi tubuh wanita terlaksana $100 \%$ sangat baik sesuai dengan fase dan unsur metode peer teaching. Pelaksanaan pembelajaran dengan menerapkan metode peer teaching siklus ketiga ini, fase dan unsur metode peer teaching sudah terlaksana dengan baik, sehingga dapat diambil kesimpulan bahwa $100 \%$ pembelajaran sudah terlaksana sangat baik sesuai dengan fase dan unsur metode peer teaching. Peningkatan kualitas pelaksanaan pembelajaran menggambar proporsi tubuh wanita dengan menerapkan metode peer teaching, dapat dilihat pada gambar 1 .

Dari hasil penerapan metode peer teaching pada pembelajaran menggambar proporsi tubuh wanita yaitu meningkat pada tiap siklusnya, maka hal ini menunjukkan bahwa adanya penyampaian informasi yang baik untuk mencapai tujuan pembelajaran. Hasil penera- pan metode peer teaching pada pembelajaran menggambar proporsi tubuh wanita yaitu meningkat, membuktikan teori dari Dimyati dan Mudjiono (2009:21-22) yaitu pembelajaran merupakan panduan belajar yang mengisyaratkan kriteria keberhasilan belajar dan diketahui siswa sebagai akibat adanya informasi guru.

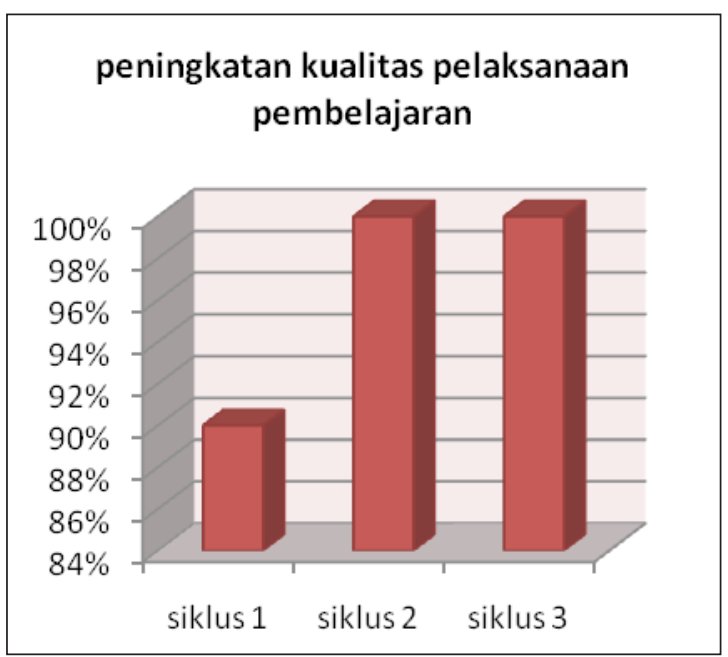

Gambar 1. Grafik Peningkatan Kualitas Pembelajaran Menggambar Proporsi Tubuh Wanita dengan Menerapkan Metode Peer Teaching

\section{Peningkatan Motivasi Belajar Siswa Melalui Penerapan Metode Peer Teaching}

Pada siklus pertama motivasi belajar siswa dalam kategori sedang dengan skor 91, dan prosentase sebesar 53,5\%, siklus kedua dalam kategori sedang dengan skor 103 dan prosentase mencapai $60,6 \%$, dan siklus ketiga dalam kategori tinggi dengan skor 128 dan prosentase mencapai $75,3 \%$. Sehingga dapat dikatakan bahwa melalui penerapan metode peer teaching ini dapat meningkatkan motivasi belajar siswa sesuai dengan indikator yang telah ditentukan. Grafik peningkatan motivasi belajar siswa siklus pertama hingga siklus ketiga dapat dilihat pada gambar 2 .

Dari hasil motivasi belajar siswa melalui penerapan metode peer teaching yaitu meningkat pada tiap siklusnya, maka hal ini menunjukkan bahwa metode peer teaching berpengaruh terhadap motivasi belajar siswa. Hasil motivasi belajar siswa pada pembelajaran menggambar proporsi tubuh wanita dengan menerapkan metode peer teaching yaitu meningkat, membuktikan teori yang dikemukakan oleh Ahcmad Rohani (2004:173) yang menyatakan bahwa 
keunggulan dari metode peer teaching yaitu 1) dapat meningkatkan interaksi antara siswa dengan siswa dan siswa dengan guru, 2) dapat meminimalisir kesenjangan yang terjadi antara siswa yang prestasinya rendah dengan siswa yang prestasinya lebih tinggi dalam suatu kelas, dan 3) dapat memotivasi siswa dalam menyelesaikan tugas.

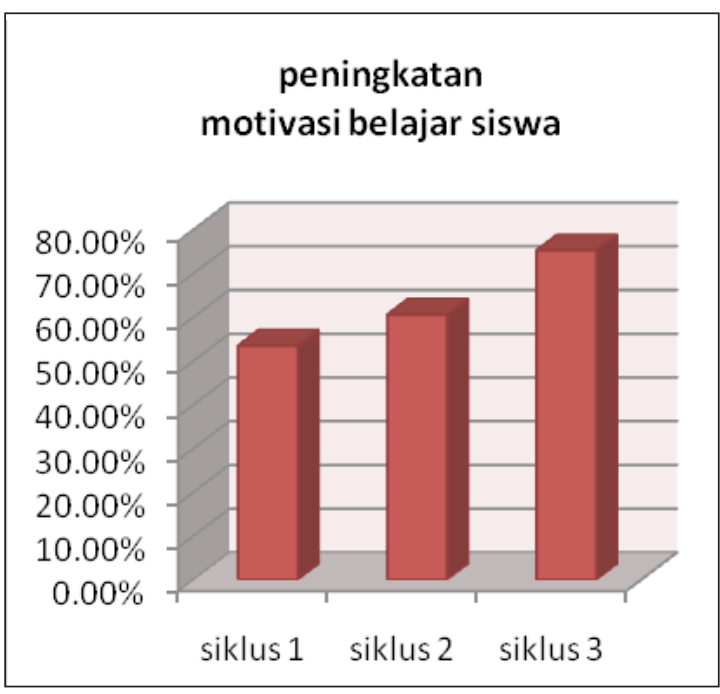

Gambar 2. Grafik Peningkatan Motivasi Belajar Siswa dengan Menerapkan Metode Peer Teaching

\section{Pencapaian Kompetensi Menggambar Pro- porsi Tubuh Wanita melalui Penerapan Metode Peer Teaching}

Melalui penerapan metode peer teaching, kompetensi menggambar proporsi tubuh wanita dapat meningkat. Hal ini dibuktikan dengan peningkatan pencapaian KKM yang ditetapkan yaitu 70. Dari 34 siswa sebelum penerapan metode peer teaching hanya 10 siswa atau $29,41 \%$ siswa yang memenuhi KKM, pada siklus pertama setelah penerapan metode peer teaching dari 34 siswa yang memenuhi KKM adalah 15 siswa atau 44,12\%. Pada siklus kedua siswa yang tuntas dan memenuhi KKM sebanyak 21 siswa atau sebesar 61,76\%. Pada siklus ketiga kedua siswa yang tuntas dan memenuhi KKM sebanyak 27 siswa atau sebesar 79,41\%. Peningkatan ini sesuai dengan kriteria keberhasilan tindakan yang ingin dicapai yaitu jumlah siswa yang dapat mencapai kompetensi dasar minimal $75 \%$ dari jumlah instruksional yang dicapai. Berikut grafik peningkatan kompetensi siswa dalam menggam- bar proporsi tubuh wanita melalui metode peer teaching siklus pertama hingga siklus ketiga.

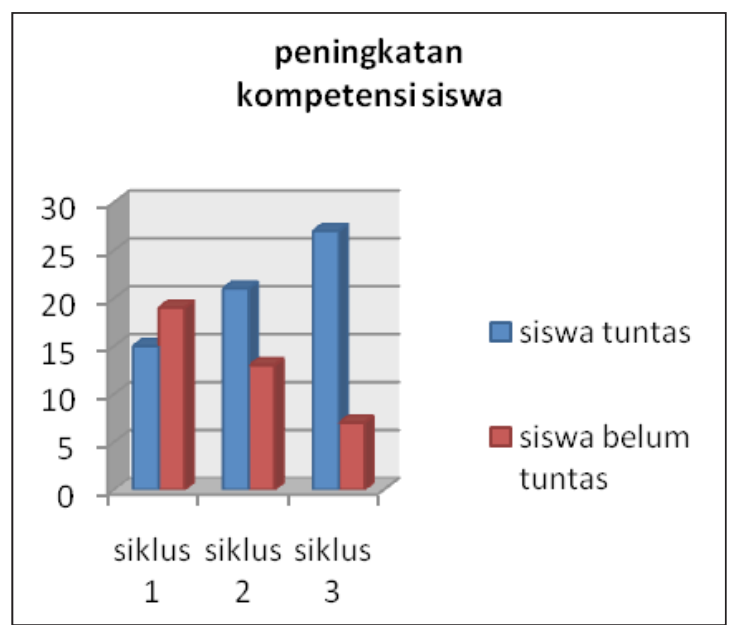

Gambar 3. Grafik Peningkatan Kompetensi Siswa dalam Menggambar Proporsi Tubuh Wanita dengan Menerapkan Metode Peer Teaching

Dari hasil pencapaian kompetensi menggambar proporsi tubuh wanita dengan menerapkan metode peer teaching yang meningkat pada tiap siklusnya, maka hal ini menunjukkan bahwa metode peer teaching berpengaruh terhadap kompetensi siswa. Peer teaching adalah sekelompok siswa yang telah tuntas terhadap bahan pelajaran, memberikan bantuan kepada siswa yang mengalami kesulitan dalam memahami bahan pelajaran yang dipelajarinya (Magel, 1996). Hasil kompetensi siswa pada pembelajaran menggambar proporsi tubuh wanita dengan menerapkan metode peer teaching yaitu meningkat, membuktikan teori yang dikemukakan oleh Dina Mellita (2008) yang menyatakan bahwa pengajaran yang dilaksanakan oleh tutor pada pengajaran terprogram dan kegiatan dipusatkan pada pencapaian kompetensi, maka dapat dinyatakan bahwa pengajaran yang dilakukan oleh tutor biasanya lebih baik dibanding dengan yang dilakukan guru.

Keterbatasan Penelitian

Dalam setiap penelitian pasti memiliki beberapa faktor yang tidak mampu dikendalikan, sehingga faktor tersebut merupakan bagian dari keterbatasan dalam penelitian. Faktor yang menjadi keterbatasan penelitian ini adalah perbedaan kemampuan siswa dalam menggambar yaitu terdapat siswa yang memiliki bakat menggambar dan ada juga yang yang tidak. 
Hal tersebut mempengaruhi dalam penilaian hasil menggambar proporsi tubuh wanita.

\section{SIMPULAN DAN SARAN}

Berdasarkan data hasil penelitian peningkatan motivasi belajar untuk pencapaian kompetensi menggambar proporsi tubuh melalui metode peer teaching pada mata pelajaran menggambar busana di SMK Diponegoro Depok Yogyakarta dan pembahasan pada bab sebelumnya maka dapat disimpulkan bahwa:

1. Pelaksanaan pembelajaran dengan menerapkan metode peer teaching, terdapat enam fase yaitu menyampaikan tujuan dan memotivasi siswa, menyajikan informasi materi, mengorganisasikan siswa ke dalam kelompok-kelompok belajar, membimbing kelompok bekerja dan belajar, evaluasi, dan memberi penghargaan. Dan unsur metode peer teaching yaitu menempatkan siswa yang berkompeten untuk menjadi peers pada kelompok belajar. Pada siklus pertama semua fase metode peer teaching terlaksana baik, namun pada saat pembagian kelompok belajar dan pengumpulan tugas belum terlaksana dengan baik. Pada siklus kedua dan ketiga semua fase metode peer teaching sudah terlaksana baik, sehingga pembelajaran menggambar proporsi tubuh wanita telah terlaksana $100 \%$ sangat baik dan sesuai dengan fase dan unsur metode peer teaching.

2. Penerapan metode peer teaching dapat meningkatkan motivasi belajar siswa, meliputi tekun (fokus dalam mengerjakan tugas), ulet (berusaha menyelesaikan tugas, memiliki daya juang tinggi), mandiri (mengerjakan tugas dengan benar tanpa bantuan orang lain), menyukai kegiatan variatif (mempunyai inisiatif yang positif dalam mengerjakan tugas dengan benar), dan dapat berargumen (menjawab pertanyaan dari guru). Hal ini ditunjukkan dari hasil pengamatan menggunakan lembar observasi yang menunjukkan bahwa motivasi belajar siswa meningkat pada siklus pertama dengan kategori sedang sebesar $53,5 \%$, pada siklus kedua dalam kategori sedang sebesar $60,6 \%$, dan pada siklus ketiga kategori tinggi sebesar $75,3 \%$. Se- hingga dapat disimpulkan bahwa dengan menerapkan metode peer teaching dapat meningkatkan motivasi belajar siswa di SMK Diponegoro Depok Yogyakarta.

3. Pencapaian kompetensi siswa dalam menggambar proporsi tubuh wanita dengan menerpkan metode peer teaching ini mengalami peningkatan di setiap siklusnya. Hal ini dibuktikan dengan meningkatnya jumlah siswa yang mencapai standar Kriteria Ketuntasan Minimal yaitu $\geq$ 70. Penerapan metode peer teaching pada siklus pertama siswa yang mencapai KKM sebanyak 15 siswa atau 44,12\%. Pada penerapan metode peer teaching pada siklus kedua siswa yang mencapai KKM sebanyak 21 siswa atau $61,76 \%$. Pada penerapan metode peer teaching pada siklus ketiga siswa yang mencapai KKM sebanyak 27 siswa atau 79,41\%. Peningkatan ini sesuai dengan kriteria keberhasilan tindakan yang ingin dicapai yaitu jumlah siswa yang memenuhi KKM sudah diatas $75 \%$. Sehingga dapat disimpulkan bahwa dengan menerapkan metode peer teaching dapat meningkatkan kompetensi menggambar proporsi tubuh wanita di SMK Diponegoro Depok Yogyakarta.

\section{Saran}

1. Pelaksanaan pembelajaran dengan menerapkan metode peer teaching sebaiknya memperhatikan fase dan unsur metode tersebut, sehingga pembelajaran dapat berlangsung kondusif dan terarah.

2. Pelaksanaan pembelajaran sebaiknya memperhatikan motivasi belajar siswa di dalam kelas, karena motivasi belajar siswa sangat berpengaruh pada keberhasilan keterlaksanaan pembelajaran dan pencapaian kompetensi siswa. Jika motivasi belajar siswa baik, maka peluang siswa untuk mencapai kompetensi juga akan lebih besar.

3. Pada saat pembelajaran menggambar proporsi tubuh wanita, sebaiknya guru memberikan pengetahuan dan selalu mengingatkan mengenai aspek-aspek penilaian yang akan digunakan seperti ketepatan ukuran, keluwesan garis gambar proporsi tubuh wanita, kerapian dan kebersihan. 
Dengan itu siswa saat mengerjakan tugas menggambar proporsi tubuh wanita akan lebih memperhatikan hal-hal tersebut, sehingga pencapaian kompetensi siswa dapat lebih baik.

\section{DAFTAR PUSTAKA}

Agus Supriyono. 2009. Cooperative learning. Yogyakarta: PT. Pustaka Belajar.

Ahcmad Rohani. (2004). Pengelolaan pembelajaran. Jakarta: Rineka Cipta

Dimyati, \& Mudjiono. (2009). Belajar dan pembelajaran. Jakarta: Rineka Cipta

Baharuddin \& Esa Nur Wahyuni. (2007). Teori belajar dan pembelajaran. Yogyakarta: Ar Ruzz Media

Dina Mellita. (2008). Metode pembelajaran peer teaching dan problem based learning untuk memotivasi sosialisasi dalam kelas. Jurnal Ilmiah Bina EDUKASI Vol.1 No., Desember 2008: 97-98

Djamarah dan Zain. (2008). Strategi belajar mengajar. Jakarta: Rineka Cipta

Hamalik Oemar. (2011). Perencanaan pengajaran berdasarkan pendekatan sistem. Jakarta: Bumi Aksara

Houtson, J. P. (1985). Motivation. New York: Macmillan Publishing Company

Joyce, Bruce., Weil, Marsha., \& Calhoun, Emily. (2009). Models of teaching model-model pengajaran (edisi delapan). (terjemahan achmad fawaid dan ateilla mirza). Yogyakarta: Pustaka Pelajar

Magel, R. (1996). Increasing students participation in large introductory statistics clasess. New York: McGraw-Hill
McLaen, Alan. (2009). Motivating every learner. London: Sage

Muhammad Joko Susilo. (2007). Kurikulum tingkat satuan pendidikan. Yogyakarta: Pustaka Pelajar

Mulyasa. (2002). Kurikulum berbasis kompetensi. Bandung: Rosda Karya

Rusman. (2012). Model Pembelajaran. Jakarta. PT Raja Grafindo Persada.

Saifudin Azwar. (2009). Metode penelitian. Yogyakarta: Pustaka Pelajar

Santrock, John W. (2011). Educational psychology. fifth edition. New York: McGraw Hill

Sardiman. (2010). Interaksi dan motivasi belajar mengajar. Jakarta: Rajawali Pers

Schunk, D.H., Patrich, P.R and Meece, J.L . (2010). Motivation in education (third edition). London: Pearson Educational LTD., London

Slavin, E. Robert. (2008). Psikologi pendidikan: teori dan praktik edisi kedelapan jilid 2. Diterjemahkan oleh Drs. Marianto Samosir. Jakarta: PT. Indeks

Sukardi. (2008). Metodologi penelitian pendidikan. Jakarta: Bumi Aksara

Suryabrata, S. (2006). Psikologi pendidikan. Jakarta: PT Raja Grafindo Persada

Syah, M. (1995). Psikologi pendidikan suatu pendekatan baru. Bandung: Remaja Rosdakarya

Wolfook, Anita Lie. (2009). Educational phychology. Boston: Pearson

Wahyu Widhiarso. (2009). Pengujian model pengukuran psikologi 1. Yogyakarta: Universitas Gadjah Mada 